\title{
Evaluation of hydrological and erosive effects at the basin scale in relation to the severity of forest fires
}

\author{
Giuseppe Coschignano, \\ Antonino Nicolaci, \\ Ennio Ferrari, \\ Francesco Cruscomagno, \\ Francesco lovino
}

\begin{abstract}
This study aimed to assess the hydrological and erosive effects of different levels of the fire severity in the drainage basin of the Trionto River (Calabria, southern Italy), which was partially burned by intense fires during the summer 2017. The analysis focused on the identification of wildfire areas using a supervised classification of remote sensing images with the minimum distance algorithm. The level of severity of each fire was then discriminated based on a procedure proposed by the U.S. Department of Agriculture and adapted to the study area. To evaluate how wildfire occurrence affects the hydrological behaviour at the basin scale, the SCS-Curve Number model was used to document pre- and post-fire conditions in relation with the level of fire severity. Finally, the influence on erosion was analysed for analogous conditions at the basin scale using the RUSLE equation. The effects on hydrological balance and soil loss were evaluated by comparing the pre-fire value with three different post-fire scenarios: (a) different levels of severity on the surface covered by the fire (real case); (b) maximum level of severity on the surface covered by the fire; (c) total loss of the canopy and formation of a hydrophobic layer on the surface soil. The results confirmed that the level of severity of the forest fires, combined with climatic factors, morphological conditions, and the pedological characteristics of the basin, significantly influence changes to the hydrology and rates of erosion. Moreover, these impacts proved to be mainly dependent on the consequent, often notable, heterogeneity in the spatial distribution of burned areas with different severity.
\end{abstract}

Keywords: Forest Fire Severity, Hydrological Impacts, Soil Loss Estimation, Remote Sensing

1980-2016 (San-Miguel-Ayanz et al. 2017) show that, on average, about 450,000 hectares of land were subjected to wildfires each year, of which $61 \%$ were concentrated between Portugal and Spain, where $68 \%$ of all fires have been recorded. Out of the remaining $39 \%$, over half of the burnt area was in Italy (105,000 ha).

In the summer of 2017, according to provisional data, the European Commission estimated that the surface covered by fires before August was 72,039 ha in Italy, 115,323 ha in Portugal, 19,666 ha in Spain, and 9,585 ha in France (Nespola 2017). High temperatures and droughts had a considerable influence in creating conditions favourable for the development and prop-

these five countries, Portugal has the greatest problem. Data for the period tugal, and Spain, which altogether represent $46 \%$ of the whole European forest cover. In these countries, over 16 million hectares were burned by about 1.8 million wildfires between 1980 and 2016, with an average of 48,000 wildfires per year. Out

Department of Computer Engineering, Modeling, Electronics, and Systems Science DIMES, University of Calabria, via P. Bucci 41C, I-87036 Rende, CS (Italy)

@ Ennio Ferrari (ennio.ferrari@unical.it)

Received: Jun 02, 2018 - Accepted: Jun 12, 2019

Citation: Coschignano G, Nicolaci A, Ferrari E, Cruscomagno F, lovino F (2019). Evaluation of hydrological and erosive effects at the basin scale in relation to the severity of forest fires. iForest 12: 427-434. - doi: 10.3832/ifor2878-012 [online 2019-08-31]

Communicated by: Angelo Nolè agation of forest fires, especially during the summer season and in certain areas. In recent years, the increase in extreme weather events has led to a greater concentration of large fires in the European Union compared to the past, increasing the areas at risk of fires northwards into Northern Europe. In the forthcoming decades, however, emergencies related to forest fires in the Mediterranean area are expected to increase, due to the likely increase in the intensity and frequency of drought and extreme temperatures, with current prevention strategies not being effective enough (Turco et al. 2017).

Fires have direct and indirect effects on the environment over the short or long term. In particular, the effects of fire are highly variable due to differences in the intensity and frequency of events, mixture of composition and structure of forest populations, and soil characteristics. For many wildfires documented in Europe, there has been a marked change in the hydrological response to precipitation, with surface runoff increasing, particularly with respect to peak flow rates rather than water volumes (Hessling 1999, McLin et al. 2001, Moody \& Martin 2001, Canfield et al. 2005). Moreover, soil resistance to erosion also Rulli \& Rosso 2005, Soto \& Diaz-Fierros declines (DeBano 1981, Inbar et al. 1998, 
1998), with the rate of erosion reaching several orders of magnitude due to certain site-specific factors (Morris \& Moses 1987). From a physical perspective, the effects of forest fires on the hydrological balance are attributed to changes in forest cover and soil properties. In particular, variations in the hydrological behaviour of the basin are associated to changes in transpiration processes, interception capacity, the onset of repellency phenomena and changes to the infiltration capacity. These phenomena are particularly noticeable in areas where high fire severity causes the volatilisation of certain organic components of the surface soil layers (DeBano et al. 1998, Inbar et al. 1998, DeBano 2000, Robichaud 2000, Shakesby \& Doerr 2006, Onda et al. 2008, Malkinson \& Wittenberg 2011, Ebel et al. 2012, Stoof et al. 2012, Moody et al. 2013).

The hydrological balance and extent of soil erosion are influenced by the behaviour and severity of the fire, type of soil, morphology, and intensity of rainfall. The behaviour of fires is analysed using different features, such as variation in the linear intensity of the flame front and residence time. The severity of fires is also measured based on the degree of ecological change resulting from their actions on the ecosystem (Morgan et al. 2001, Lentile et al. 2006, Hudak et al. 2007). Burn severity reflects how fire affects vegetation and soil characteristics, which subsequently determine runoff responses. Usually, burn severity is classified into discrete descriptive classes (such as high, moderate, and low), which reflect the degree of removal of both the canopy layer and the ground cover (Key \& Benson 2005). At small scales (up to 100 $\mathrm{m}^{2}$ ), burn severity is assessed using physi- cal tests, such as soil measurements of water infiltration (Robichaud et al. 2008) and the water drop penetration time test (DeBano 1981). At larger scales (hillslope to basin scales), a reliable metric of soil burn severity is derived from Landsat imagery, as proposed by the U.S. Department of Agriculture (USDA) Forest Service (Parson et al. 2010). Specifically, soil burn severity is assessed based on changes to land surface reflectance between two Landsat satellite images for near and short-wave infrared bands (difference between post- and prefire Normalized Burn Ratio, $\triangle N B R$ ). From a practical perspective, $\triangle N B R$ values may be clustered into qualitative values of high, moderate, and low soil burn severity classes; however, different number of classes and thresholds have been used across studies (Cocke et al. 2005, Chafer et al. 2008). Furthermore, some studies using remote sensing have had difficulty in discriminating fire severity classes for certain vegetation communities (Rogan \& Franklin 2002).

This study investigates how wildfires influenced a drainage basin located in Calabria (southern Italy) during July-August 2017. Specifically, the study examined major fire events lasting several days over a large portion of wooded territory on the Sila Plateau. The aim is to explore the potential of remote sensing via satellites to evaluate how the hydrology and erosion rates of the basin were impacted by different levels of fire severity.

\section{Materials and methods}

\section{Study area}

The drainage basin of the Trionto River is part of the Sila Greca (Calabria, Italy), which is located in the northeastern sector of the Sila Plateau. The river flows into the Ionian Sea, and the total area of the basin is 288 $\mathrm{km}^{2}$. From a geomorphological perspective, the basin is subdivided into two parts with distinct characteristics. Higher elevations and steep slopes characterise the mountainous part, while the valley part has a gentler morphology, with a riverbed in the terminal section containing large quantities of debris, that configure the typical braided course of the Calabrian rivers, called "fiumare".

This study focused on a sub-basin of the Trionto River that was strongly impacted by wildfires from 15 July to 31 August, 2017. The drainage area of the sub-basin is 8497 ha, of which $0.3 \%$ are urbanised. The maximum and mean elevations of the sub-basin are 1644 and $1089 \mathrm{~m}$ a.s.l., respectively, with mean slope of $40 \%$. The study site is located in the southwestern, mountainous part of the Trionto drainage basin (Fig. 1). This location is very difficult to access, due to its morphological complexity, resulting in it being characterised by high density of forest populations. The fire also made access to the site difficult, preventing on-site ground surveys for post-fire condition inspections; thus, it was only possible to perform photographic examination of the soils.

During the mid-1950s, large areas of this basin were reforested to address the geological instability of the region. The main tree species used was Calabrian pine (Pinus nigra J.F. Arn. ssp. laricio [Poiret] Maire), which is a hardy endemic species of the region. Because the area is composed of heavily eroded granites and shales soils

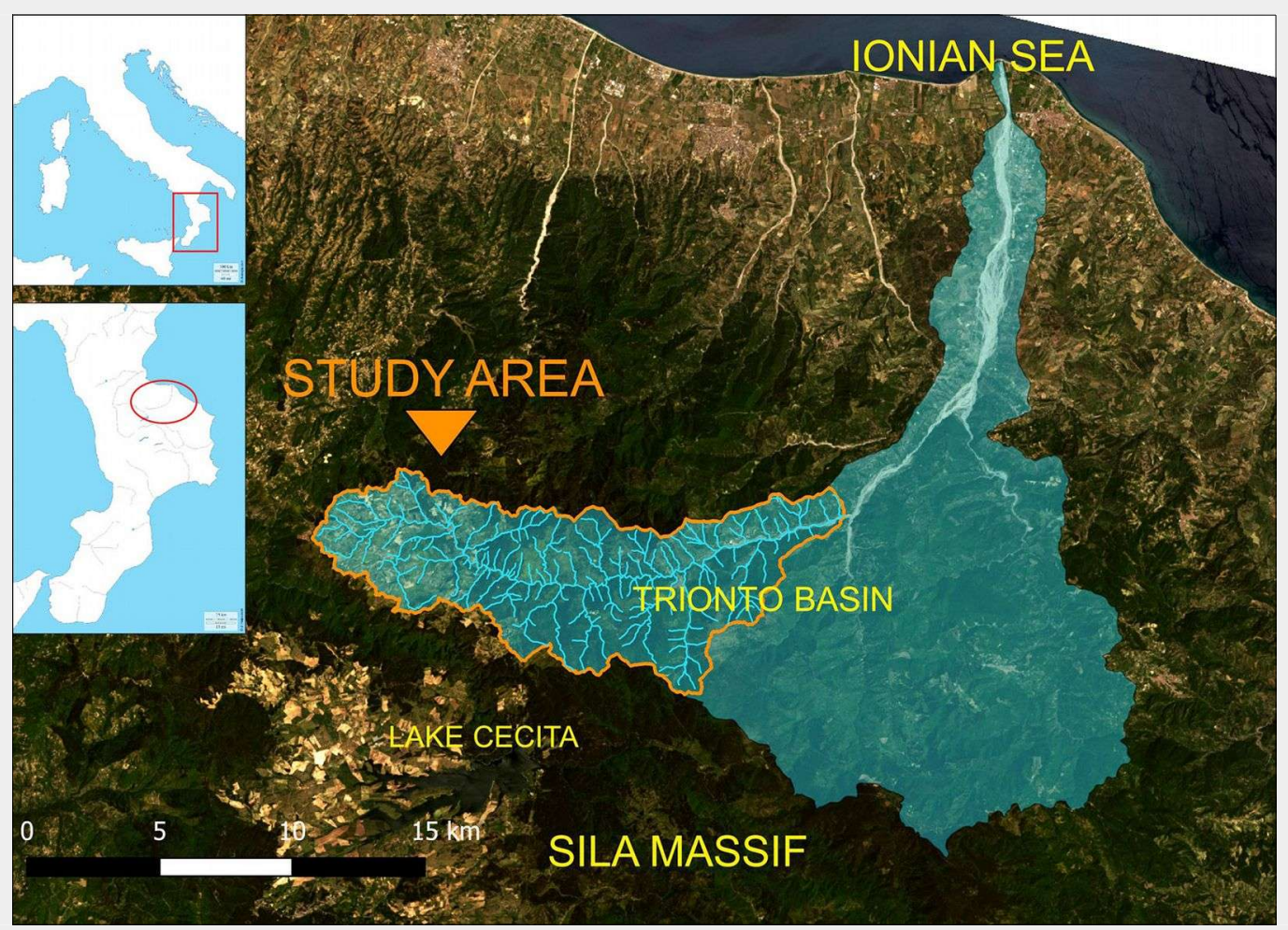

Fig. 1 - Study area. 
characterised by steep slopes, land uses, other than forests, were not possible. Specifically, the sub-basin is composed of soils belonging to the $\mathrm{V}$ and the $\mathrm{VI}$ classes of the soil capability, according to the Land Capability Classification (Dimase \& Iovino 1996).

The different land use classes of the subbasin were delineated from IV level of the Corine Land Cover (see Fig. S1 in Supplementary Material for the original data used in this analysis). The main land use of the sub-basin is forests, which cover $48.8 \%$ of the whole area (Tab. 1).

The soils exhibit the specific associations listed in Tab. 2, which are linked to the corresponding drainage classes (Dimase \& lovino 1996).

\section{Classification of burned areas related to different degrees of severity}

During the summer of 2017 (July-August), a series of forest fires affected a large percentage of the study area. The most relevant events lasted for four consecutive weeks (from July 31 to August 26), and impacted a large, partially forested, area between Acri and Longobucco, which are two large municipalities of the Presila and Sila Greca in southern Italy.

All fire events that occurred in the study area during the observed period were detected using a Sentinel-2, Level 1-C image. An image acquired on September 2, 2017 with a $10 \mathrm{~m}$ spatial resolution was used. The potential of the Near Infra-Red was exploited, which shows strong absorption for the burnt vegetated areas. Thus, the false colour combination in the 8-4-3 bands depicted burned areas as dark grey and living vegetation as red (see Fig. S2 in Supplementary Material for the original data used in this analysis).

The area exposed to the fires was bounded through the supervised classification procedure of the satellite image using the Minimum Distance algorithm, trained by means of the ROI (Region Of Interest) approach. This algorithm classifies each pixel in an image by calculating the Euclidean distance $d(x, y)$ between the spectral signature of the pixel and a training spectral signature that is defined for each specific macro-class as follows (eqn. 1):

$$
d(x, y)=\sqrt{\sum_{i=1}^{n}\left(x_{i}-y_{i}\right)^{2}}
$$

where $x_{\mathrm{i}}$ is the vector of the pixel's spectral signature, $y_{i}$ is the vector of the training spectral signature, and $n$ is the number of spectral bands.

The accuracy of classifying unburned vs. burned areas was assessed using test sites for which satellite images were subject to photo interpretation. Specifically, a confusion matrix was created, which obtained an overall accuracy of almost 90\%. The kappa index of agreement was about 0.8 , showing acceptable accordance between the classification map and reference data (Congalton \& Green 2009).

Tab. 1 - Percentage of land use in the sub-basin.

\begin{tabular}{|lc}
\hline Land use & Area (\%) \\
\hline 1 - Discontinuous urban territory & 0.3 \\
\hline - Intensive crops & 20.2 \\
\hline - Crop system and complex particles & 0.1 \\
\hline 4 - Crops with presence of important natural areas & 2.7 \\
\hline - Woods with prevalence of holm oaks & 2.5 \\
\hline 6 - Mixed and pure woods with prevalence of deciduous oak & 3.5 \\
\hline 7 - Woods with prevalence of chestnut & 3.4 \\
\hline - Pine plantation and natural pine forest & 25.2 \\
\hline - Beech forest with sparse Calabrian pine area spatiality & 11.4 \\
\hline 10 - Mixed Calabrian pine - beech forest & 2.8 \\
\hline 11 - Grassland and grazing & 5.1 \\
\hline 12 - High Mediterranean scrub & 4.2 \\
\hline 14 - Low Mediterranean scrub and garrigue & 3.0 \\
\hline 15 - Alluvial areas & 14.8 \\
\hline
\end{tabular}

To determine the level of fire severity, the FireMon procedure (Lutes et al. 2006) was used. This procedure uses the NBR (Normalized Burn Ratio) index, which is equivalent to the normalised difference between near infrared and short-wave infrared (eqn. 2):

$$
N B R=\frac{N I R-S W I R}{N I R+S W I R}
$$

This index quantifies the difference between two optical-satellite acquisitions that are spatially homogeneous but have a temporal shift (pre-fire and post-fire conditions), in which (eqn. 3):

$$
\Delta N B R=N B R_{\text {pre }}-N B R_{\text {post }}
$$

For this purpose, two Landsat-8 images from May 14, 2017 and September 19, 2017 with a $30 \mathrm{~m}$ spatial resolution were used.

The $\triangle N B R$ index is based on satellite reflectance, which is associated with water content. Fig. 2 shows the deviation between normally distributed cumulative probability functions (CDFs) assumed by the $\triangle N B R$ index for data from two prevailing land use types in the burned area (forested areas and sparse vegetation).

This high deviation led to the different land uses being considered separately when classifying the severity of wildfires to avoid the impacts being underestimated. Thus, according to the difference between the average values assumed by the $\triangle N B R$ index for the two land uses (delta), the severity rating was adapted to the forested area by using intervals suggested by FireMon. The extreme values of the intervals were reduced by a fraction of the delta using a trial and error approach, with the aim to achieve a good match between the resulting severity areas of FireMon and the accurate burned areas of Sentinel-2. It was not possible to ground-truth the results because of the difficulty in accessing the

Tab. 2 - Classes of soil drainage.

\begin{tabular}{ll}
\hline Associations of soils & Drainage class \\
\hline $\begin{array}{l}\text { Typic Xerofluvents; Fluventic and Dystric Fluventic } \\
\text { Xerochrepts }\end{array}$ & Excessively drained \\
\hline $\begin{array}{l}\text { Lithic and Dystric Xerorthens, Dystric Xerochrepts, } \\
\text { Lithic Xerumbrepts }\end{array}$ & Excessively drained \\
\hline $\begin{array}{l}\text { Dystric Fluventic Xerochrepts, Dystric Xerochrepts, } \\
\text { Typic Xerumbrepts; Lithic Xerorthens }\end{array}$ & Excessively drained \\
$\begin{array}{l}\text { Typic Xerumbrepts; Ultic Haploxeralfs, Entic and Lithic } \\
\text { Xerumbrepts, Dystric and Dystric Lithic Xerumbrepts }\end{array}$ & Somewhat excessively drained \\
\hline $\begin{array}{l}\text { Typic Haplumbrepts; Lithic Haplumbrepts and Ultic } \\
\text { Hapludales }\end{array}$ & Somewhat excessively drained \\
\hline $\begin{array}{l}\text { Lithic Ruptic-Xerorthentic Xerochrepts, Typic and } \\
\text { Dystric Xerochrepts }\end{array}$ & Well drainage \\
\hline $\begin{array}{l}\text { Lithic Xerorthens And Lithic Ruptic-Xerorthentic } \\
\text { Xerochrepts; Typic and Ruptic-Lithic Xerochrepts }\end{array}$ & Moderately well drained \\
$\begin{array}{l}\text { Ultic Haploxeralf; Dystric Xerochrepts and Dystric } \\
\text { Xerorthens }\end{array}$ & Moderately well drained \\
$\begin{array}{l}\text { Dystric, Aquic Distric and Typic Xerochrepts; Lithic } \\
\text { Xerorthens, Ultic and Aquultic Haploxeralfs }\end{array}$ & Somewhat poorly drained \\
\hline
\end{tabular}




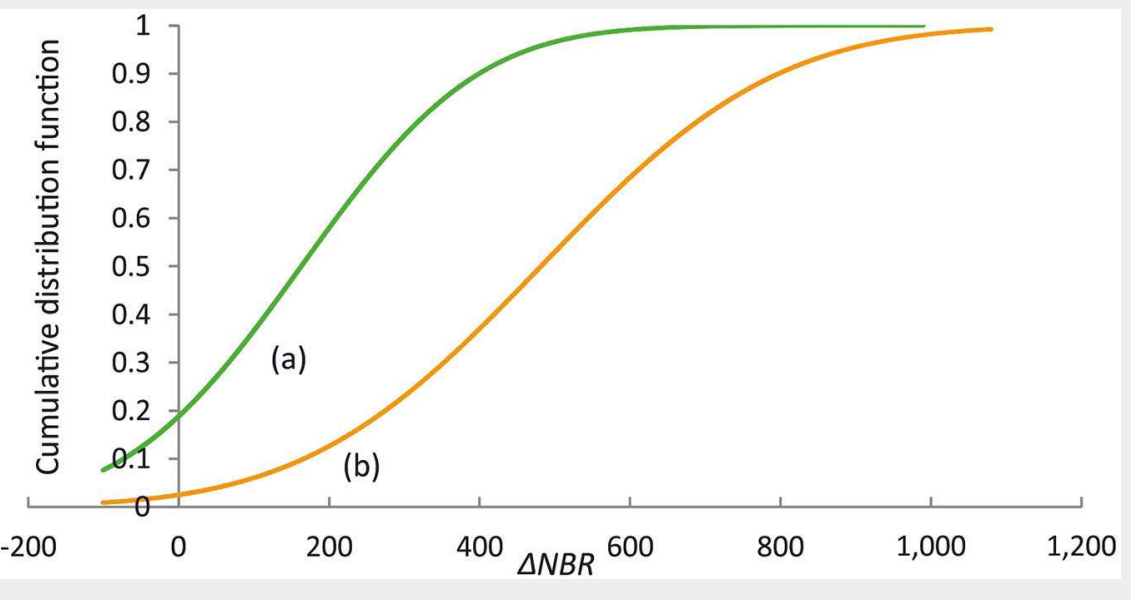

Fig. 2 - Variation in the cumulative distribution functions (CDF) of the $\triangle N B R$ for two prevailing land uses in the basin: (a) forested areas; (b) sparse vegetation.

Tab. 3 - Level of severity of forest fires.

\begin{tabular}{lc}
\hline Level of severity & $\Delta$ NBR interval \\
\hline Very low & $-100 \rightarrow 98$ \\
\hline Low & $99 \rightarrow 268$ \\
\hline Moderate & $269 \rightarrow 438$ \\
\hline High & $439 \rightarrow 659$ \\
\hline Very high & $660 \rightarrow 1188$ \\
\hline
\end{tabular}

Tab. 4 - Variation in the parameters $\mathrm{CN}$, $\mathrm{C}$ and $\mathrm{K}$ corresponding to the different levels of severity of forest fires.

\begin{tabular}{lrcc}
\hline \multirow{2}{*}{$\begin{array}{l}\text { Level of } \\
\text { severity }\end{array}$} & \multicolumn{3}{c}{$\begin{array}{c}\text { Variation from } \\
\text { pre-fire condition }\end{array}$} \\
\cline { 2 - 4 } & $C N$ & $C(\%)$ & $K(\%)$ \\
\hline Low & +5 & +40 & +40 \\
Moderate & +10 & +60 & +60 \\
\hline High & +15 & +80 & +80 \\
Very high & +20 & +100 & +100 \\
\hline
\end{tabular}

study site. Some consequences were observed only at limited sites that were accessible, and which were surveyed using pictures (Fig. 3). Thus, the choice of comparing results from different products and techniques appears cautionary. Tab. 3 reports the severity levels that were identified and the corresponding intervals of the $\triangle N B R$ index.

\section{Application of the SCS-CN model to estimate hydrological effects}

How forest fires impacted the hydrology at the basin scale was estimated using the SCS-CN model (USDA 1986). This model is frequently used to evaluate surface runoff at the river basin scale. The model takes pre-fire and post-fire conditions into account, and discriminates the different levels of severity based on the procedure reported in the BAER Hydrology Special Report (Higginson \& Jarnecke 2007). In the SCS-CN model, infiltration losses are com- bined with surface accumulation through eqn. 4:

$$
Q=\frac{\left(P-I_{a}\right)^{2}}{P-I_{a}+S}
$$

where $Q(\mathrm{~mm})$ is the excess rain, $P(\mathrm{~mm})$ is the height of rainfall and $l_{\mathrm{a}}(\mathrm{mm})$ is the initial abstraction, commonly assumed as (eqn. 5):

$$
I_{a}=0.2 \mathrm{~S}
$$

Parameter S (sorptivity) is the maximum retention potential of the soil, given by (eqn. 6):

$$
S=S_{0}\left(\frac{1000}{C N}-10\right)
$$

where the scale factor $S_{0}$ is equal to 254 $\mathrm{mm}$ (10 inches), while the parameter $\mathrm{CN}$ (dimensionless, ranging from o to 100) depends on land use, hydrological soil type and antecedent soil moisture (AMC, index of soil wetness - USDA 1986). CN under pre-fire conditions $\left(\mathrm{CN}_{\text {pre }}\right)$ is evaluated as the weighted average of the catchment area. It is calculated by combining information provided by land use and hydrological soil type (A, B, C or D), which is selected based on the runoff potential of the corresponding soil unit. The same parameter was obtained under post-fire conditions $\left(\mathrm{CN}_{\text {post }}\right)$ through procedures documented in the BAER Report, which considers a constant numerical increase of $\mathrm{CN}_{\text {post }}$ in relation to the severity level of the fire (Tab. 4).

Differences in sorptivity were calculated as a function of $\mathrm{CN}$ under pre-fire and postfire conditions, by quantifying hydrological effects due to fires at the basin scale. Specifically, the effects were evaluated by comparing pre-fire conditions with three different post-fire scenarios: (a) different levels of severity to the burned area (realis-

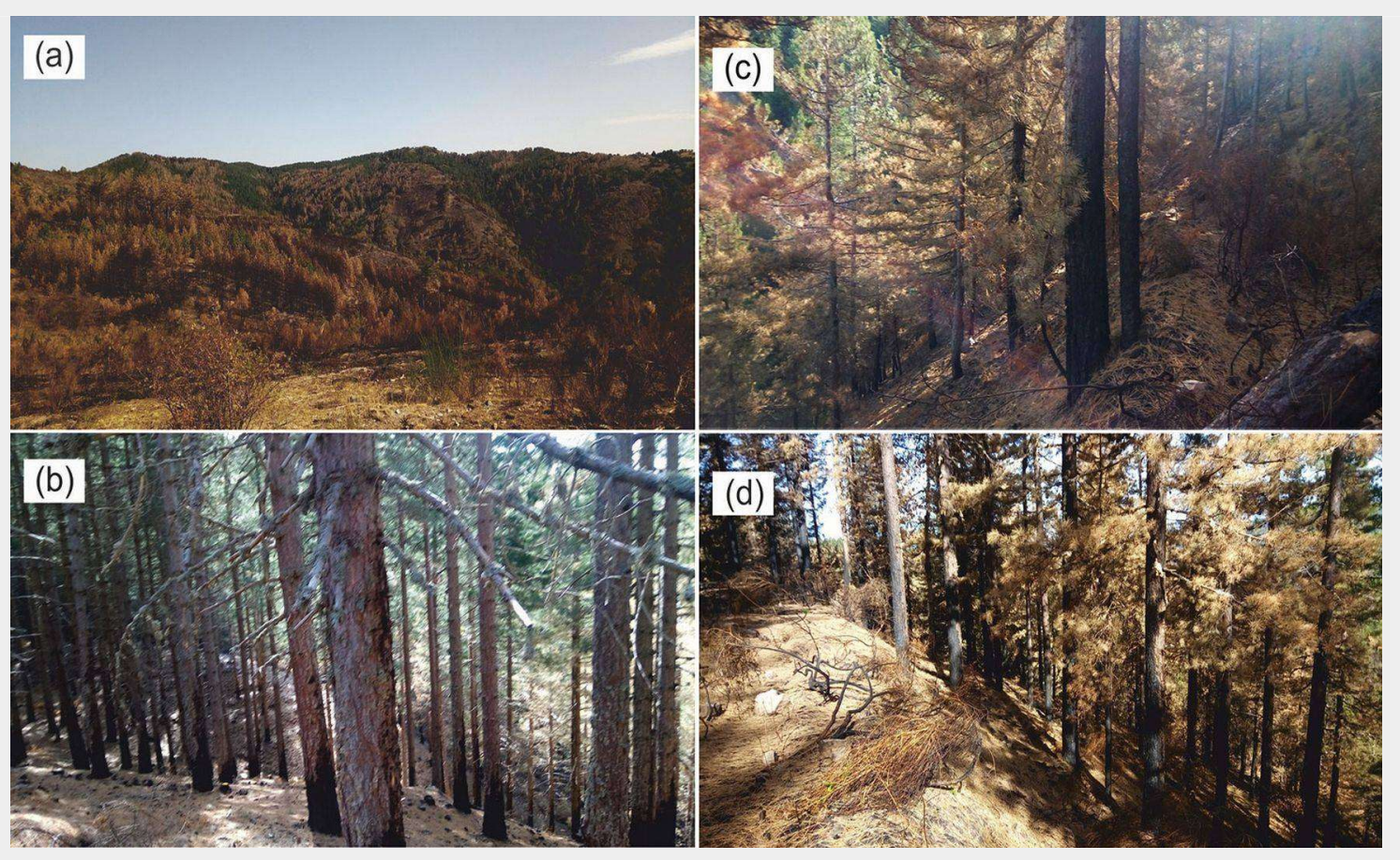

Fig. 3 - Effect of forest fires on the Trionto basin. (a) Heterogeneity of fire severity in a burned area; (b) reforestation of Calabrian pine (Pinus nigra) affected by low fire severity; (c) reforestation of Calabrian pine affected by mean fire severity; (d) reforestation of Calabrian pine affected by high fire severity. 
tic scenario); (b) maximum level of severity to the burned area; (c) complete loss of the canopy and waterproofing of the burned area (worst case scenario). These three scenarios were used to establish a reasonable impact framework where uncertainty prevents precise estimates.

\section{Application of the RUSLE model to estimate soil loss}

The erosive effects of forest fires on the basin were assessed by applying at the basin scale the equation which has been adopted and revised by the U.S. Department of Agriculture as RUSLE (Revised Universal Soil Loss Equation - Wischmeier \& Smith 1978). The RUSLE equation introduces new parameters allowing the model to be better described, even on morphologically complex terrains. This equation is based on an empirical parametric model that estimates average annual soil loss rates caused by surface water erosion. The USLE-RUSLE model is based on the following relationship (eqn. 7):

$$
A=R K L_{S} C P
$$

where $A$ is the mean annual value of soil loss $\left(M g h a^{-1} y^{-1}\right), R$ is the rainfall erosivity factor $\left(\mathrm{MJ} \mathrm{mm} \mathrm{h} \mathrm{ha}^{-1} \mathrm{~h}^{-1}\right), K$ is the soil erodibility factor ( $M g h^{-1} \mathrm{MJ}^{-1} \mathrm{~mm}^{-1}$ ha $\mathrm{h}$ ), $L_{s}$ is the topographic factor or slope length factor (dimensionless), $C$ is the soil coverage (dimensionless), and $P$ is a factor that depends on erosion control practices (dimensionless). The product among the factors, except for rainfall erosivity, provides a measure of resistance of the environment to erosive phenomena. The $R$ factor is influenced by the intensity and the duration of precipitation, namely, the kinetic energy of the rain is transformed to mechanical energy on impact with the surface. Therefore, this phenomenon depends on the geographic-climatic location of the different parts of the basin. The $R$ factor for the study area was obtained from a raster map constructed for a previous application of RUSLE in Calabria at regional scale (Terranova et al. 2009).

The soil-erodibility $K$ factor is a measure of soil susceptibility to erosion. This parameter depends on certain physical properties of the soil that influence the infiltration capacity and the movement of water within the soil. It also depends on properties that affect the dispersion, abrasion and mobility of soil constituent particles. The $K$ factor was assigned based on values from the published literature, with the zoning of the pedological units of the area being taken into account (Dimase \& lovino 1996, Terranova et al. 2009).

The topographic factor $L_{s}$ takes into account the length $(L)$ and the slope $(S)$ of hills, because the extent of erosion processes is influenced by the association of these two factors. Several methods have been proposed to improve the calculation of $L_{s}$; however, sufficient accuracy has only recently been achieved due to advances in GIS and digital elevation models (DEM) for the RUSLE calculation. To quantify the convergence or divergence of superficial runoff, the $L$ factor was replaced by the concept of "unit contributing area" (Moore \& Burch 1986, Mitasova et al. 1996, Desmet \& Govers 1996). Thus, it is possible quantify the areas contributing to runoff and the direction of surface runoff on the raster cell grid (flow accumulation grid), which is necessary to apply the finite difference equations to calculate $L_{s}$ in a two-dimensional raster environment. A simple form of the equation used to compute $L_{s}$ is (Griffin et al. 1988, Moore \& Wilson 1992, Mitasova et al. 1996 - eqn. 8):

$$
L_{S}=(m+1)\left(\frac{A_{s}}{22.13}\right)^{m}\left(\frac{\sin (b)}{0.0896}\right)^{n}
$$

where $A_{s}(m)$ is the upslope contributing area per unit contour width (for this study, it was assessed using $\operatorname{ArcGIS}^{\circledast}$ functions "flowacc" and "resolution"); $b$ is the slope, $m=0.4$ (value range: $0.2-0.6$ ) and $n=1.3$ (value range: 1.0-1.3 - Mitasova et al. 1996). The results were in good accordance with previous researches in the study area (Bosco et al. 2015, Panagos et al. 2015).

The cover-management $C$ factor quantifies the effect of land cover, and is influenced by both land use and management. Low $C$ values (equal or close to 0 ) are attributed to areas with dense tree vegetation that limit the potential rate of soil erosion. In comparison, values close to 1 are assigned to poorly protective crops, such as grassland, grazing and open vegetation, or to soil subjected to mechanical agricultural processes that favour erosion. The support-practise $P$ factor ranges from 0 to 1 , and represents possible practices for erosion control, aimed essentially at reducing surface runoff (such as terracing and intercropping).

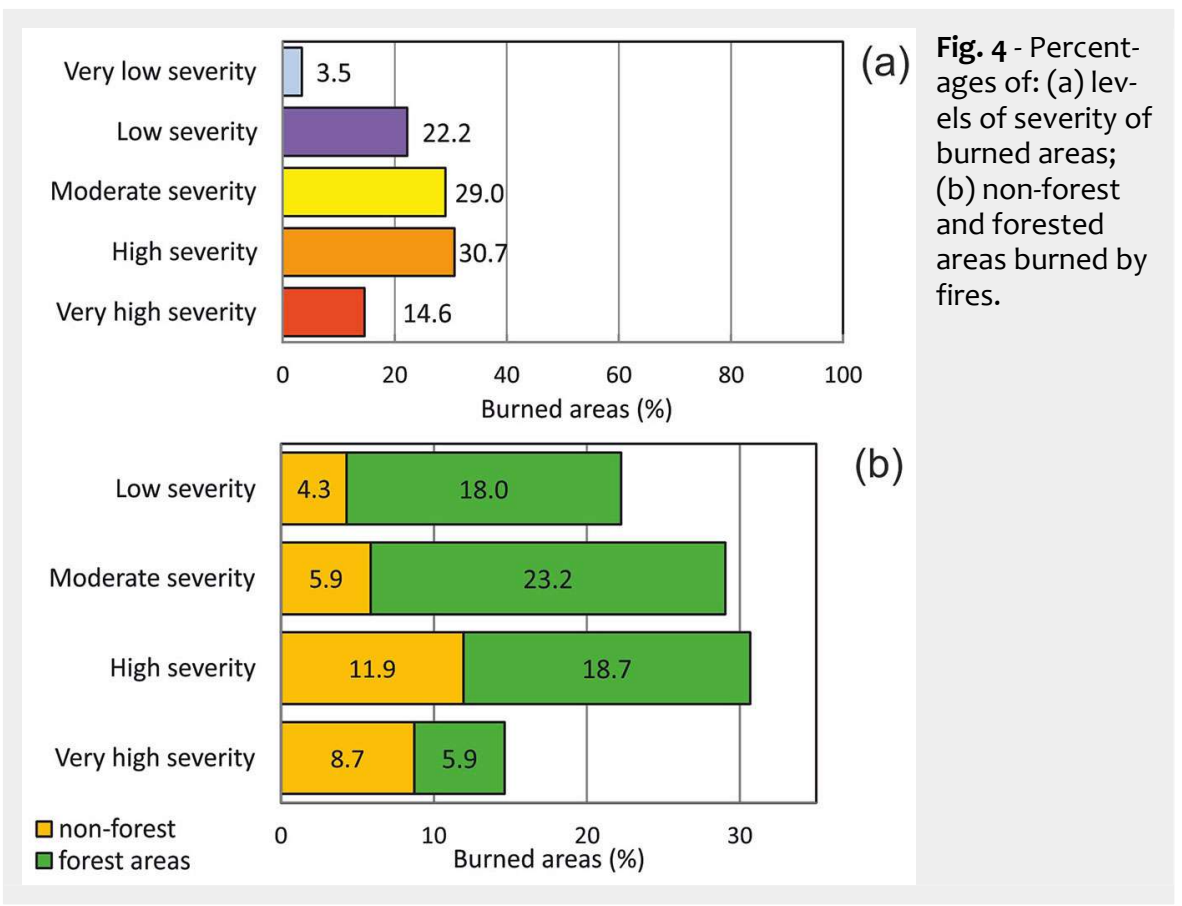

The USLE-RUSLE model was applied by creating raster layers (40 $\mathrm{m}$ spatial resolution) related to the study area for each of the considered factors. The erodibility rate under pre-fire conditions was obtained as a mean value at the basin scale. This procedure was replicated to estimate variation in erodibility rates under post-fire conditions. Thus, the consequent effects were considered, especially changes to forest cover, the consumption of organic substances in the soil and the reduction of surface roughness, which induce changes to $C$ and $K$. It is assumed that the variation in the original values of these factors progressively increases with the level of severity (Tab. 4) (Terranova et al. 2009). The three aforementioned scenarios were used to evaluate how pre-fire and post-fire conditions affect soil loss.

\section{Results}

The section of the Trionto sub-basin analysed in this study is mainly characterised by soils with good hydrological efficiency, based on their high retention capacity, limiting detrimental effects caused by excess surface runoff. The varying magnitude of the wildfire events of the summer of 2017 caused spatial variation in forest cover. The areas covered by fires were grouped according to levels of severity (Fig. 4a). For each level, the percentages of non-forest and forested areas were evaluated (Fig. $4 b)$.

The sub-basin was primarily covered by two types of land use: forested areas (about 66\%) and sparse and evolving areas (about 27\% - see Fig. S3a in Supplementary Material for the original data used in this analysis). The sparse and evolving areas were mainly re-afforestation areas, and were the same zones in which repeated fires in previous years destroyed the forest cover. The forested areas exposed to fires 
Fig. 5 - (a) Subdivision of the burned areas according to different levels of severity; (b) burned areas.

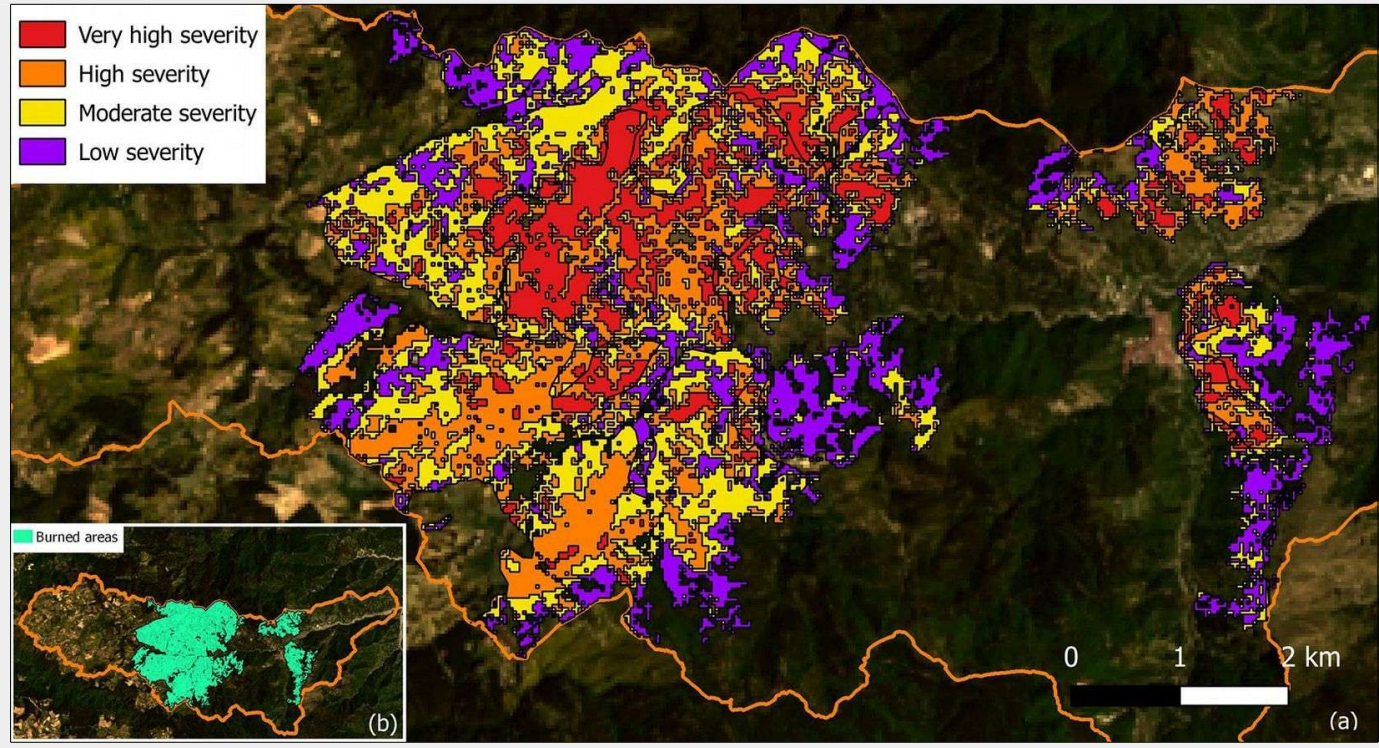

were almost completely (90\%) pine plantations and natural pine forests (see Fig. S3b in Supplementary Material for the original data used in this analysis).

Fig. 5 shows the zoning of the burned area for the different levels of severity. The fire covered a total area of 2357 ha, which was equal to $28 \%$ of the whole sub-basin area. About $55 \%$ of the burned area was exposed to fires of moderate and low severity (Fig. 4a).

Tab. 5 shows the values of hydrological balance and soil erosion of the study area obtained using the $\mathrm{CN}$ method (parameters $C N$ and $S$ ) and RUSLE method (mean annual value of soil erosion) under pre-fire and post-fire conditions based on the three scenarios. The averaged $\mathrm{CN}$ estimates for the entire basin show that the impact increased with increasing severity of fires under the three scenarios. Anyway, the actual proportion of the high-severity burned areas in the basin is crucial for their quantification, as shown by the $\mathrm{CN}$ values, which increased from $5 \%$ to $9 \%$ between the actual status (scenario a) and the modelled maximum level of severity (scenario $b$ ). $C N$ only reached $21 \%$ in the scenario where the canopy was completely lost and the burned area was waterproofed (scenario c); however, this situation is rare. A corresponding decrease in sorptivity was detected (evaluated as the change to maximum retention potential $\Delta S$, in comparison with the pre-fire condition), demonstrating

Tab. 5 - Estimates of curve number $(C N)$ and sorptivity $(S)$, and variation in $S(\Delta S)$ between pre-fire and post-fire conditions. Mean annual value of soil erosion $(A)$ and its variation from the reference value $(\Delta A)$.

\begin{tabular}{llcccc}
\hline Scenario & $C N$ & $\begin{array}{c}S \\
(\mathbf{m m})\end{array}$ & $\begin{array}{l}\Delta S \\
(\%)\end{array}$ & $\begin{array}{c}A \\
\left(\mathbf{M g ~ h a}^{-1} \mathrm{y}^{-1}\right)\end{array}$ & $\begin{array}{c}\Delta A \\
(\%)\end{array}$ \\
\hline Pre-fire & 63 & 149 & - & 25 & - \\
\hline Post-fire - scenario a & 66.2 & 130 & -13 & 31 & +24 \\
\hline Post-fire - scenario b & 68.4 & 117 & -21 & 36 & +44 \\
\hline Post-fire - scenario c & 76.1 & 80 & -47 & $>100$ & $>100$ \\
\hline
\end{tabular}

that the basin was subject to higher runoff after wildfires. The loss of hydrological efficiency between pre-fire and post-fire conditions was quantified using the $S$ parameter. $S$ declined by $13 \%$ for scenario a and $21 \%$ for scenario b. Under scenario c, $\Delta S$ clearly declined (47\%).

Based on RUSLE, variation in C and $\mathrm{K}$ under the post-fire conditions was attributed to canopy loss due to the wildfires; consequently, rainfall impacted the soil with greater energy. As the ability of the soil to absorb water declined, greater runoff occurred, particularly on very steep slopes characterised by burnt areas. This phenomenon contributed towards increasing the amount of sediment transport. The pre-fire value for soil erosion was comparable to the tolerable value for maximum annual soil loss in highly erodible areas (up to 25 Mg ha-1 $\mathrm{y}^{-1}$ ) delineated by Kirkby \& Morgan (1980), because the Trionto basin is characterised by highly eroded soils and large precipitation. Under scenario a, the mean annual value of soil erosion increased by $24 \%$, and rose to $44 \%$ under scenario b (maximum level of severity), as shown in Tab. 5 . Under scenario $c$, the mean annual value of soil erosion exceeded $100 \%$ that of the prefire value.

\section{Discussion}

Damaging wildfires impacted a large area of forested land on the Sila Plateau in southern Italy over several days in 2017.
However, accessing these remote areas was difficult to establish appropriate onsite ground surveys of post-fire conditions, requiring the adoption of alternative approaches. Thus, this study compared the effectiveness of different satellite products and different scenarios to quantify how wildfires impacted the hydrology and erosion rates of the study area. The supervised classification of the burned areas was performed using a Sentinel-2 image, with the kappa index being used to establish accuracy. The results of this approach showed good agreement with ground truthing (Landis \& Koch 1977). The overall accuracy was similar to that reported by Chirici \& Corona (2006) for a forest fire in central Italy. Landsat images were used to assess the level of severity of fires based on previous studies, in which NBR represented the most optimal index derived from Landsat TM and ETM+ sensors when mapping burn severity (Epting et al. 2005, Chafer 2008, Escuin et al. 2008). This approach allowed $\triangle N B R$ to be evaluated effectively by exploiting improved signal-to-noise ratios and the enhanced radiometric resolution of Landsat- 8 under highly heterogeneous scenarios. This procedure involved the comparison of burned areas using two different satellite products, which helped to avoid errors in zoning the level of fire severity.

The hydrological status of the sub-basin before and after the fires was assessed using $\mathrm{CN}$, with pre-fire values being closely related to the good condition of forest coverage in the area. In comparison, post-fire $\mathrm{CN}$ indicated the partial loss of hydrological efficiency. This phenomenon was also highlighted by changes to sorptivity $(\Delta S)$, which became less significant over time (Papathanasiou et al. 2015, Soulis 2018). In particular, the comparison between the three post-fire scenarios showed how the increase in $C N$ values and the loss in sorptivity $(\Delta S)$ assumes relevant values only with the complete destruction of the canopy 
and the waterproofing of the land $(\Delta S$ decreased to about half that of the initial average retention capacity). Under scenario a (the real situation, with different levels of severity), there was a moderate loss of hydrological efficiency, which increased when the whole basin was affected by the maximum level of fire severity (scenario $b$ ). The $\mathrm{CN}$ under the three scenarios were very similar to that obtained by Leopardi \& Scorzini (2015) for the San Giuliano basin in Abruzzo (Central Italy). Differences between pre-fire and post-fire values of $\mathrm{CN}$ detected in our study were comparable (percentage-wise) to those obtained by Candela et al. (2005) in a Sicilian basin (southern Italy), based on eqn. 6 for sorptivity $S$ and using data for two rainfallrunoff events post-fire. At the basin scale, the average retention potential was closely related to the increase in surface runoff, and strongly impacted hydraulic efficiency in the valley part of the Trionto basin, which is historically vulnerable to flooding.

Under the scenario with no discrimination of fire severity, there was a noticeable increase in soil loss (erosion), particularly when compared to scenario a (actual situation). The mean rate of soil loss estimated by RUSLE is generally higher than that of point measured values in Mediterranean fire-affected areas (Shakesby 2011). However, the three scenarios explored in this study provided results that were in good agreement with the soil erosion risk scenarios evaluated by Terranova et al. (2009) for Calabria at a regional scale. These results show that hydrological and erosive effects are progressively significant if areas affected by high fire severity are spatially large within the drainage basin. Thus, a proper evaluation of the effects at the basin scale is strictly related not only to the correct identification of the entire burned areas but also to the accurate zoning of severity levels. If neglected, this would lead to a heavy biased estimation of the fire impacts, which makes hard to prioritise recovery interventions at a large scale.

\section{Conclusions}

This study quantified how wildfires impacted a sub-basin of the Trionto River (southern Italy) under three different postfire scenarios, by evaluating changes to the hydrology (water balance) and soil erosion rates in burned areas subjected to different levels of fire severity. The hydrological (SCS-CN) and the erosive (RUSLE) models allowed some of the main impacts of forest fires on the sub-basin to be characterised. Consequently, the basin proved to be strongly influenced by variation in fire severity, due to the importance of heterogeneity in the spatial distribution of burned areas. The level of severity of burned areas to the total surface area represents a fundamental element for the correct evaluation of hydrological and erosive parameters of the basin after wildfires. By overlooking these parameters, the effects might be overestimated, hindering the accurate interpretation of the impact of fires. This phenomenon was demonstrated by the substantial differences recorded between realistic and worst case scenarios. The methodology developed here provided a reasonable framework for establishing the priorities for post-fire recovery actions. Specifically, this study allowed the hydrological responses of the basin to be quantified, which could be used in flood risk assessments.

\section{Acknowledgements}

GC and FC carried out the GIS elaborations; AN performed the statistical analysis; $\mathrm{FI}$ and GC conceived the study; FI, EF and GC wrote the paper. All authors contributed to the discussion.

\section{References}

Bosco C, De Rigo D, Dewitte O, Poesen J, Panagos $P$ (2015). Modelling soil erosion at European scale: towards harmonization and reproducibility. Natural Hazards and Earth System Sciences 15: 225-245. - doi: 10.5194/nhess-15-2252015

Candela A, Aronica G, Santoro M (2005). Effects of forest fires on flood frequency curves in a Mediterranean catchment. Hydrological Sciences Journal 50 (2): 193-206. - doi: 10.1623/hysj. 50.2.193.61795

Canfield HE, Goodrich DC, Burns IS (2005). Application of models to predict post-fire runoff and sediment transport at the watershed scale in southwestern forests. In: Proceedings of the "2005 Watershed Management Conference Managing Watersheds for Human and Natural Impacts: Engineering, Ecological, and Economic Challenges" (Moglen GE ed). American Society of Civil Engineers, Reston, VA, USA, pp. 1-12.

Chafer CJ (2008). A comparison of fire severity measures: an Australian example and implications for predicting major areas of soil erosion. Catena 74 (3): 235-245. - doi: 10.1016/j.catena. 2007.12.005

Chafer CJ, Noonan M, Macnaught E (2008). The post-fire measurement of fire severity and intensity in the Christmas 2001 Sydney wildfires. International Journal of Wildland Fire 13: 227240. - doi: 10.1071/WF03041

Chirici G, Corona P (2006). Utilizzo di immagini satellitari ad alta risoluzione nel rilevamento delle risorse forestali [Use of high-resolution satellite images for forest resources surveying]. Aracne Editrice, Rome, Italy, pp. 192. [in Italian] Cocke AE, Fulè PZ, Crouse JE (2005). Comparison of burn severity assessments using differenced normalized burn ratio and ground data. International Journal of Wildland Fire 14: 189-198. doi: 10.1071/WF04010

Congalton RG, Green K (2009). Assessing the accuracy of remotely sensed data: principles and practices ( $2^{\text {nd }}$ edn). CRC Press, Taylor and Francis Group, Boca Raton, FL, USA, pp. 183.

DeBano LF (1981). Water repellent soils: a state of the art. General Technical Report PSW-46, USDA Forest Service, Pacific Southwest Forest and Range Experiment Station, Berkeley, CA, USA, pp. 25. [online] URL: http://www.fs.usda. gov/treesearch/pubs/26997
DeBano LF, Neary DG, Ffolliott PF (1998). Fire's effects on ecosystems. John Wiley and Sons, New York, USA, pp. 159-196.

DeBano LF (2000). The role of fire and soil heating on water repellency in wildland environments: a review. Journal of Hydrology 231-232: 195-206. - doi: 10.1016/So022-1694(00)00194-3

Desmet PJJ, Govers G (1996). A GIS procedure for automatically calculating the USLE LS factor on topographically complex landscape units. Journal of Soil and Water Conservation 51: 427433. [online] URL: http://www.jswconline.org/ content/51/5/427.short

Dimase AC, lovino F (1996). I suoli dei bacini idrografici del Trionto, Nicà e torrenti limitrofi (Calabria). [The soils of the Trionto and Nicà drainage basins and conterminous rivers (Calabria, Italy)]. Accademia Italiana di Scienze Forestali, Nuova Stamperia, Firenze, Italy, pp. 112. [in Italian]

Ebel BA, Moody JA, Martin DA (2012). Hydrologic conditions controlling runoff generation immediately after wildfire. Water Resources Research 48 (3): 329. - doi: 10.1029/2011WR011470 Epting J, Verbyla D, Sorbel B (2005). Evaluation of remotely sensed indices for assessing burn severity in interior Alaska using Landsat TM and ETM+. Remote Sensing of Environment 96 (34): 328-339. - doi: 10.1016/j.rse.2005.03.002

Escuin S, Navarro R, Fernández P (2008). Fire severity assessment by using NBR (Normalized Burn Ratio) and NDVI (Normalized Difference Vegetation Index) derived from LANDSAT TM/ ETM images. International Journal of Remote Sensing 29 (4): 1053-1073. - doi: 10.1080/0143116 0701281072

Griffin M, Beasley D, Fletcher J, Foster G (1988). Estimating soil loss on topographically nonuniform field and farm units. Journal of Soil and Water Conservation 43: 326-331. [online] URL: http://www.jswconline.org/content/43/4/326.sh ort

Hessling M (1999). Hydrological modelling and pair basin study of Mediterranean catchments. Physics and Chemistry of the Earth, Part B: Hydrology, Oceans and Atmosphere 24 (1-2): 5963. - doi: 10.1016/S1464-1909(98)00012-4

Higginson B, Jarnecke J (2007). Salt Creek BAER2007 burned area emergency response. Hydrology Specialist Report, Uinta National Forest, Provo, UT, USA, pp. 11.

Hudak AT, Morgan P, Bobbitt MJ, Smith AMS, Lewis SA, Lentile LB, Robichaud PR, Clark JT, McKinley RA (2007). The relationship of multispectral satellite imagery to immediate fire effects. Journal of Fire Ecology 3: 64-90. [online] URL: http://link.springer.com/article/10.4996/fi reecology.0301064

Inbar M, Tamir M, Wittenberg L (1998). Runoff and erosion processes after a forest fire in Mount Carmel, a Mediterranean area. Geomorphology 24: 17-33. - doi: 10.1016/S0169-555X(97) 00098-6

Key C, Benson N (2005). Landscape assessment: ground measure of severity; the Composite Burn Index, and remote sensing of severity, the Normalized Burn Index. In: "FIREMON: Fire Effects Monitoring and Inventory System". General Technical Report RMRS-GTR-164-CD, USDA Forest Service, Rocky Mountain Research Station, Fort Collins, CO, USA, pp. 1-51. 
Kirkby MJ, Morgan RPC (1980). Soil erosion. John Wiley and Sons, Chichester, UK, pp. 316.

Landis JR, Koch G (1977). The measurement of observer agreement for categorical data. Biometrics 33 (1): 159-174. - doi: 10.2307/2529310

Lentile LB, Holden ZA, Smith AMS, Falkowski MJ, Hudak AT, Morgan P, Lewis SA, Gessler PE, Benson NC (2006). Remote sensing techniques to assess active fire characteristics and postfire effects. International Journal of Wildland Fire 15: 319-345. - doi: 10.1071/WF05097

Leopardi M, Scorzini AR (2015). Effects of wildfires on peak discharges in watersheds. iForest - Biogeosciences and Forestry 8 (3): 302-307. doi: 10.3832/ifor1120-007

Lutes DC, Keane RE, Caratti JF, Key CH, Benson NC, Sutherland S, Gangi $\sqcup$ (2006). FIREMON: fire effects monitoring and inventory system. General Techical Report RMRS-GTR-164-CD, NRRC, USDA Forest Service, Rocky Mountain Research Station, Fort Collins, CO, USA, pp. 400. - doi: 10.2737/RMRS-GTR-164

Malkinson D, Wittenberg $L$ (2011). Post fire induced soil water repellency - modeling short and long-term processes. Geomorphology 125: 186-192. - doi: 10.1016/j.geomorph.2010.09.014

MCLin SG, Springer EP, Lane LJ (2001). Predicting floodplain boundary changes following the Cerro Grande wildfire. Hydrological Processes 15 (15): 2967-2980. - doi: 10.1002/hyp.385

Mitasova H, Hofierka J, Zlocha M, Iverson LR (1996). Modeling topographic potential for erosion and deposition using GIS. International Journal of Geographical Information Science 10 (5): 629-641.

Moody JA, Martin DA (2001). Post-fire, rainfall intensity-peak discharge relations for three mountainous watersheds in the western USA. Hydrological Processes 15: 2981-2993. - doi: 10.1002/hyp.386

Moody JA, Shakesby RA, Robichaud PR, Cannon $\mathrm{SH}$, Martin DA (2013). Current research issues related to post-wildfire runoff and erosion processes. Earth-Science Reviews 122: 10-37. - doi: 10.1016/j.earscirev.2013.03.004

Moore ID, Burch GJ (1986). Physical basis of the length-slope factor in the universal soil loss equation. Soil Science Society of America 50 (5): 1294-1298. - doi: 10.2136/sssaj1986.03615995 $005000050042 x$

Moore ID, Wilson J (1992). Length-slope factors for the revised universal soil loss equation: simplified method of estimation. Journal of Soil and Water Conservation 47: 423-428. [online] URL: http://www.jswconline.org/content/47/5/4 23.short

Morgan P, Hardy CC, Swetnam TW, Rollins MG, Long DG (2001). Mapping fire regimes across time and space: understanding coarse and finescale fire patterns. International Journal of Wildland Fire 10: 329-342. [online] URL: http://
www.publish.csiro.au/wf/WF01032

Morris SE, Moses TA (1987). Forest fire and the natural soil erosion regime in the Colorado Front Range. Annals of the Association of American Geographers 77: 245-254. - doi: 10.1111 /j.1467-8306.1987.tbo0156.x

Nespola N (2017). Roghi nella Ue: serve una cultura della prevenzione. Quali interventi si stanno adottando? II problema è sia l'emergenza in atto, sia la prospettiva di lungo termine [Forest fires in the EU: a culture of prevention is needed. What interventions are they taking? The problem is both the ongoing emergency and the long-term perspective]. Web site. [in Italian] [online] URL: http://www.lind ro.it/roghi-nella-ue-serve-cultura-della-prevenzi one

Onda Y, Dietrich WE, Booker F (2008). Evolution of overland flow after a severe forest fire. Point Reyes, California. Catena 72: 13-20. - doi: 10.1016/j.catena.2007.02.003

Panagos P, Borrelli P, Meusburger K (2015). A new european slope length and steepness factor (LS-Factor) for modeling soil erosion by water. Geosciences 5: 117-126. - doi: 10.3390/geosci ences5020117

Papathanasiou C, Makropoulos C, Mimikou M (2015). Hydrological modelling for flood forecasting: calibrating the post-fire initial conditions. Journal of Hydrology 529: 1838-1850. doi: 10.1016/j.jhydrol.2015.07.038

Parson A, Robichaud PR, Lewis SA, Napper C, Clark JT (2010). Field guide for mapping postfire soil burn severity. General Techical Report RMRS-GTR-243, USDA Forest Service, Rocky Mountain Research Station, Fort Collins, CO, USA, pp. 49. - doi: 10.2737/RMRS-GTR-243 Robichaud PR (2000). Fire effects on infiltration rates after prescribed fire in northern Rocky Mountain forests, USA. Journal of Hydrology 231-232: 220-229. - doi: 10.1016/So022-1694(00) 00196-7

Robichaud PR, Lewis SA, Ashmun LE (2008). New procedure for sampling infiltration to assess post-fire soil water repellency. Research Note RMRS-RN-3, USDA Forest Service, Rocky Mountain Research Station, Fort Collins, CO, USA, pp. 14. - doi: 10.2737/RMRS-RN-33

Rogan J, Franklin J (2002). Mapping wildfire burn severity in southern California forests and shrublands using enhanced thematic mapper imagery. Geocarto 16: 89-99.

Rulli MC, Rosso R (2005). Modeling catchment erosion after wildfires in the San Gabriel Mountains of southern California. Geophysical Research Letters 32: L19401. - doi: 10.1029/2005GL 023635

San-Miguel-Ayanz J, Durrant T, Boca R, Libertà G, Branco A, De Rigo D, Ferrari D, Maianti P, Artés Vivancos T, Schulte E, Loffler P (2017). Forest Fires in Europe, Middle East and North Africa
2016. EUR 28707 EN, EU Publications Office, Luxembourg, pp. 126.

Shakesby RA, Doerr SH (2006). Wildfire as a hydrological and geomorphological agent. EarthScience Reviews 74: 269-307. - doi: 10.1016/j.ear scirev.2005.10.006

Shakesby RA (2011). Post-wildfire soil erosion in the Mediterranean: review and future research directions. Earth-Science Reviews 105 (3-4): 71100. - doi: 10.1016/j.earscirev.2011.01.001

Soto B, Diaz-Fierros F (1998). Runoff and soil erosion from areas of burnt scrub: comparison of experimental results with those predicted by the WEPP model. Catena 31: 257-70. - doi 10.1016/S0341-8162(97)00047-7

Soulis KX (2018). Estimation of SCS curve number variation following forest fires. Hydrological Sciences Journal 63 (9): 1332-1346. - doi: 10.1080/02626667.2018.1501482

Stoof CR, Vervoort RW, Iwema J, Van Den Elsen E, Ferreira AJD, Ritsema CJ (2012). Hydrological response of a small catchment burned by experimental fire. Hydrology and Earth System Sciences 16: 267-285. - doi: 10.5194/hess-16-2672012

Terranova O, Antronico L, Coscarelli R, laquinta P (2009). Soil erosion risk scenarios in the Mediterranean environment using RUSLE and GIS: an application model for Calabria (southern Italy). Geomorphology 112: 228-245. - doi: 10.101 6/j.geomorph.2009.06.009

Turco M, Von Hardenberg J, AghaKouchak A, Llasat MC, Provenzale A, Trigo RM (2017). On the key role of droughts in the dynamics of summer fires in Mediterranean Europe. Scientific Reports 7 (1): 11. - doi: 10.1038/s41598-01700116-9

USDA (1986). Urban hydrology for small watersheds. Technical Release 55, USDA, Washington, DC, USA, pp. 164.

Wischmeier WH, Smith DD (1978). Predicting rainfall erosion losses: a guide to conservation planning. Agriculture Handbook no. 537, USDA, Washington DC, USA, pp. 13-27. [online] URL: http://www.cabdirect.org/cabdirect/abstract/19 786726437

\section{Supplementary Material}

Fig. S1 - Soil use map (CLC-IV level).

Fig. S2 - SENTINEL-2, Level 1-C image. Representation of the band set=8-4-3.

Fig. S3 - (a) Distribution of land uses in the burned area; (b) distribution of burned forest areas.

Link: Coschignano_2878@supploo1.pdf 